\title{
EFEKTIVITAS EDTA DALAM MEMBERSIHKAN LAPISAN KERAK PADA CAGAR BUDAYA BERBAHAN BATU
}

\author{
Ari Swastikawati, Fr. Dian Ekarini, dan Sri Wahyuni \\ Balai Konservasi Borobudur \\ arie_swastik@yahoo.com
}

\begin{abstract}
ABSTRAK : Candi-candi di Indonesia umumnya terletak di kawasan yang terbuka sehingga sangat terpengaruh dengan kondisi cuaca dan iklim sekitarnya. yang dapat memicu kerusakan dan pelapukan batu candi. Efek lingkungan yang sering ditemukan adalah timbulnya lapisan-lapisan kerak pada permukaan batu candi yang menutupi batu, yang dapat berupa endapan garam yang berwarna putih, maupun lumut (moss), algae (ganggang) dan lichen (jamur kerak). Kajian ini dilakukan dalam rangka untuk mencari metode yang tepat untuk membersihkan lapisan-lapisan kerak yang ada pada permukaan batu candi sehingga kelestariannya dapat terjaga. Metode pembersihan yang dilakukan adalah dengan menggunakan larutan EDTA (ethylene diamine tetraacetic acid) dengan berbagai konsentrasi untuk menentukan konsentrasi yang paling efektif untuk membersihkan lapisan kerak serta menentukan lamanya waktu kontak. Berdasarkan hasil kajian diperoleh data bahwa konsentrasi EDTA dan lamanya waktu kontak tidak berpengaruh terhadap tingkat kalarutan lapisan kerak yang ada di Candi Borobudur, Candi Mendut dan Candi Kalasan.

Konsentrasi larutan EDTA 3-5\% dengan waktu kontak 24 jam paling efektif melarutkan kalsium (Ca), magnesium ( $\mathrm{Mg}$ ) pada candi Kalasan dan Mendut, serta besi ( $\mathrm{Fe}$ ) dan tembaga $(\mathrm{Cu})$ pada lapisan kerak di Candi Kalasan.

Sementara itu, di lapisan kerak Candi Mendut larut maksimal dalam EDTA 15\% waktu kontak 24 jam. $\mathrm{Ca}, \mathrm{Mg}$, Fe dan Cu pada lapisan kerak Candi Borobudur dapat larut secara maksimal dalam larutan EDTA dengan konsentrasi 10\% dengan kontak waktu 24 jam. Dari analisis EDS (energy dispersive spectroscopy) komposisi lapisan kerak terdiri dari unsur logam dan non logam. Larutan EDTA hanya mampu melarutkan unsur logam dengan tingkat kelarutan yang sangat rendah, sedangkan unsur non logam tidak larut. Secara umum metode ini belum efektif untuk membersihkan lapisan kerak yang menempel pada batu candi.

Kata Kunci: Cagar budaya batu, pembersihan kerak, EDTA
\end{abstract}

ABSTRACT : The temples in Indonesia are generally located in an open area so they are easily affected by weather conditions and the surrounding climate, that stimulate weathering process of the stone temple. The effects of the weather is ussually seen as the crust that indicating salt deposits, moss, algae and lichens. This research was conducted in order to find appropriate methods to clean up the layers of crust that exist on the surface of the stones so that weathering can be inhibited. The Cleaning method studied is using solution of EDTA (ethylene diamine tetraacetic acid) with various concentrations to determine the most effective concentration to clean the crust layer and determines the length of contact time. The research data results showed that the concentration of EDTA as 3-5\% with a contact time of 24 hours contribute highest dissolving calcium (Ca), magnesium (Mg) in the stone of Mendut and Kalasan Temple and and iron (Fe) and copper (Cu) in the crust layer in Kalasan. Meanwhile Fe in the crust layer Mendut can be maximally dissolved in 15\% EDTA with contact time of 24 hours. $\mathrm{Ca}, \mathrm{Mg}, \mathrm{Fe}$, and $\mathrm{Cu}$ in the crust layer at Borobudur Temple can be maximally dissolved in EDTA solution with concentration of $10 \%$ and the contact time of 24 hours . From EDS analysis (energy dispersive spectroscopy) of the crust, it is found that the crurst is composed by metal and non-metal elements. The solution of EDTA can only dissolve the metals from the crusts, but it can not dissolve the nonmetallic elements. In general, this method is less effective for cleaning the crust layer on the stone temple .

Keyword : Stone heritage, crust cleaning, EDTA

\section{PENDAHULUAN}

\section{Latar Belakang Penelitian}

Bangunan candi pada umumnya terletak di wilayah yang terbuka sehingga sangat terpengaruh oleh cuaca dan ilkim di lingkungan sekitarnya. Hal ini memungkinkan bangunan cagar budaya yang berupa bangunan candi dapat mengalami kerusakan dan pelapukan. Faktor-faktor iklim yang berpengaruh terhadap proses kerusakan dan pelapukan ini diantaranya adalah suhu, kelembaban udara, sinar matahari, hujan, angin dan sebagainya.

Kerusakan pada bangunan candi berbahan batu misalnya retak, pecah, renggang, sedangkan akibat dari proses pelapukan adalah munculnya lapisan putih pada permukaan batu yang sering disebut sebagai endapan garam. Selain itu, pelapukan yang disebabkan oleh mikroorganisme adalah munculnya lumut (moss), algae (ganggang) dan lichen (jamur kerak). Lapisan-lapisan kerak yang ada di permukaan batu 
candi khususnya di Candi Borobudur sangat banyak ragamnya. Ada lapisan berwarna putih yang sering kita sebut endapan garam, lapisan oker (occer) yang berwarna kuning dan lapisan-lapisan akibat aktivitas mikroorganisme. Juga terdapat adanya pustule (bisulbisul batu) dan alveoli (bisul batu yang telah pecah). Lapisan-lapisan permukaan batu ini muncul tidak hanya di Candi Borobudur saja melainkan juga pada candi-candi batu lainnya termasuk Candi Mendut dan Candi Kalasan.

Lapisan kerak yang berwarna putih sebenarnya juga tidak hanya terdiri dari garam saja tapi didalamnya juga terdapat berbagai macam kandungan yang saling bertumpuk dan berlapis-lapis. Proses pembentukkan lapisan kerak ini sangat panjang prosesnya. Diawali dengan adanya air hujan yang jatuh menerpa batu candi kemudian masuk ke dalam batu-batu candi, kemudian karena adanya sinar matahari maka terjadilah penguapan air. Proses transport air terjadi dari dalam batu menuju ke permukaan batu karena adanya penguapan air dengan membawa mineralmineral batuan. Pada saat proses penguapan air tersebut air menguap dan mineral-mineral batuan tadi tertinggal di permukaan batuan memberntuk suatu lapisan-lapisan permukaan yang sering kita sebut dengan endapan garam. Lapisan-lapisan kerak pada permukaan batu ini sangat bervariasi ada yang sudah lama terbentuk sehingga tingkat kekerasannya tinggi dan ada yang belum lama terbentuk sehingga masih lunak dan mudah dibersihkan.

Lapisan-lapisan kerakyang terbentuknya sudah lama, sulit untuk dihilangkan karena sudah sangat keras dan biasanya sudah menyatu dengan permukaan batu candi. Penggaraman ini harus dihentikan atau paling tidak dikendalikan karena akan mengancam kelestarian Candi Borobudur dan candi-candi lainnya. Lapisan-lapisan kerakiniakan menyebabkan reliefcandi rusak dan mengelupas. Balai Konservasi Borobudur selaku instansi yang bertanggung jawab untuk memelihara Candi Borobudur selalu berupaya dalam melakuakan konservasi batu terutama penanganan masalah-masalah tersebut. Namun hingga saat ini penggaraman atau lapisan-lapisan kerak ini masih menjadi permasalahan yang belum terpecahkan secara maksimal.

UNESCO sebagai lembaga dunia yang menangani cagar budaya dunia juga telah mengirimkan expert dari Italia untuk membantu Balai Konservasi Borobudur untuk mengatasi permasalahanpermasalahan konservasi batu candi. Pada tahun 2006, 2008, dan 2011 seorang ahli konservasi Prof. Costantino Meuccii melakukan pendampingan kegiatan konservasi di Candi Borobudur. Materi yang diberikan selama pendampingan berisi tentang jenis dan penyebab kerusakan dan pelapukan, bagaimana cara mengobservasinya, dan kemungkinan cara penanganannya. Beberapa rekomendasi dari hasil pendampingan tersebut antara lain observasi pelapukan secara digital menggunakan komputer agar memperoleh data yang akurat, penanganan endapan garam menggunakan beberapa bahan kimia antara lain EDTA (ethylene diamine tetraacetic acid) dan $\mathrm{NH}_{4} \mathrm{HCO}_{3}$ (amonium bi karbonat).

Pemilihan EDTA sebagai media pelarutan didasarkan pada kenyataaan bahwa senyawa-senyawa organik yang dapat berperan sebagai asam lemah, reduktor, dan agen pengompleks suatu logam, serta dapat melarutkan logam tersebut dari oksidanya. Molekul EDTA merupakan ligan yang dapat membentuk senyawa kompleks yang larut dalam berbagai ion logam termasuk $\mathrm{Ca}$, Fe dan Mg. Sebagai tindak lanjut rekomendasitersebut maka Balai Konservasi Borobudur pada 2010 mengadakan Kajian yang berjudul "Metode Konservasi Relief Candi Borobudur".

Dalam kajian "Metode Konservasi Relief Candi Borobudur" pada tahun 2010 digunakan dua bahan pelarut yaitu $\mathrm{NH}_{4} \mathrm{HCO}_{3}$ (amonium bikarbonat) dan EDTA (ethylen diamine tetra acetic acid). Hasil penelitian tersebut menunjukkan bahwa larutan $\mathrm{NH}_{4} \mathrm{HCO}_{3}$, EDTA dan campurannya memiliki kemampuan untuk melarutkan kalsium (Ca) dari endapan garam pada batu relief Candi Borobudur. Tetapi perlakuan kedua pelarut tersebut dengan konsentrasi 3\%, 5\%, 10\% belum terlihat secara nyata membersihkan endapan garam pada permukaan relief tersebut. Tingkat kelarutan garam kalsium tertinggi pada larutan EDTA $10 \%$ dengan waktu kontak 1,5 bulan sebesar 333,23 ppm. Berdasarkan hasil kajian tersebut maka perlu dilaksanakan kajian lanjutan pada tahun 2012, yang lebih difokuskan pada efektivitas EDTA dalam melarutkan endapan garam pada batu candi, dengan perlakuan berbagai konsentrasi dan metode yang baru.

\section{Maksud dan Tujuan Penelitian}

Maksud dari kajian "Efektivitas EDTA dalam Membersihkan Lapisan Kerak Pada Cagar Budaya Berbahan Batu" adalah untuk mencari metode yang paling tepat dalam mengatasi lapisan kerak yang terdapat pada batu candi. Adapun tujuan dari kajian ini adalah:

1) Mengetahui efektifitas aplikasi larutan kimia EDTA (ethylene diamine tetraacetic acid) dalam membersihkan lapisan kerak pada permukaan batu candi.

2) Menentukan konsentrasi EDTA (ethylene diamine tetraacetic acid) yang paling tepat untuk membersihkan lapisan kerak pada 
permukaan batu candi.

3) Menentukan lama waktu aplikasi EDTA yang tepat untuk membersihkan lapisan kerak pada permukaan batu candi.

\section{Manfaat Penelitian}

Hasil kajian ini diharapkan dapat menjadi pedoman dalam penanganan lapisan kerak atau endapan garam pada permukaan batu candi.

\section{Ruang Lingkup}

Ruang lingkup dalam kajian ini dibatasi pada endapan garam atau lapisan kerak pada permukaan batu Candi Borobudur, Candi Kalasan, dan Candi Mendut. Larutan uji yang digunakan adalah EDTA (ethylene diamine tetraacetic acid) dengan konsentrasi 10\%, 15\% dan 20\% untuk Candi Borobudur, dan konsentrasi 3\%, 5\%, 10\%, dan 15\% untuk Candi Mendut dan Candi Kalasan.

\section{Metode Penelitian}

Metode penelitian yang dilaksanakan dalam kegiatan kajian ini antara lain studi literatur atau studi pustaka, observasi lapangan, eksperimen berserta analisis laboratorium dan monitoring beserta digitalisasi.

\section{a. Studi Pustaka}

Studi pustaka atau literatur dilaksanakan untuk mencari literatur-literatur yang relevan dengan tema kajian ini. Pencarian literatur dilaksanakan di perpustakaan Balai Konservasi Borobudur, dan penelusuran melalui internet.

\section{b. Observasi Lapangan}

Observasi dilaksanakan sebelum eksperimen dan sesudah eksperimen di Candi Borobudur, Candi Mendut, dan Candi Kalasan. Kegiatan observasi lapangan sebelum ekperimen dilaksanakan untuk menentukan lokasi yang akan dijadikan tempat eksperimen. Dalam observasi awal ini juga dilakukan pemotretan serta digitalisasi luas endapan garam untuk memperoleh data mengenai luas endapan garam sebelum perlakuan.

Observasi setelah eksperimen dilaksanakan untuk mengetahui pengaruh perlakuan bahan kimia terhadap kelarutan endapan garam/lapisan kerak. Dalam observasi ini juga dilaksanakan pemotretan kemudian dilakukan digitalisasi data.

\section{c. Eksperimen di lapangan}

Eksperimen atau percobaan di lapangan bertujuan untuk menentukan konsentrasi bahan kimia EDTA yang paling tepat dan menentukan lamanya waktu aplikasi yang paling efektif untuk membersihkan lapisan kerak/endapan garam pada permukaan candi batu.

1. Pembuatan larutan EDTA konsentrasi $3 \%, 5 \%, 10 \%, 15 \%$ untuk Candi Mendut dan Candi Kalasan dan 10\%, 15\%, 20\% untuk Candi Borobudur.

2. Membuat media berupa bubur kertas/ tissue yang diberi larutan EDTA dengan berbagai konsentrasi.

3. Penempelan bubur kertas pada lokasi sampel.

4. Pengamatan selama 24 jam, 48 jam dan 72 jam dengan mengganti media bubur kertas setiap pengamatan.

5. Setiap pemasangan/penggantian media bubur kertas, sebelumnya dilakukan pembersihan mekanis dengan sikat dan air.

\section{d. Analisis Laboratorium}

Analisis laboratorium dilaksanakan adalah analisis EDS (Energy Dispersive Spectroscopy) untuk mengetahui komposisi unsur-unsur kimia dari sampel lapisan kerak/endapan garam yang diambil.dan analisis AAS (Atomic Absorption Spectrophotometer) untuk menentukan tingkat kelarutan lapisan kerak/endapan garam dalam EDTA. Analisis EDS dilakukan di Laboratorium SEM (Scanning Electron Microscope) Fakultas MIPA, Institut Teknologi Bandung, sedangkan untuk analisis AAS dilakukan di Laboratorium Analitik, Fakultas MIPA, UGM.

\section{e. Digitalisasi Luasan sampel endapan garam/ lapisan kerak}

Foto sebelum dan sesudah perlakuan dibandingkan untuk memperoleh luasan lapisan kerak/endapan garam yang berhasil dibersihkan.

\section{HASIL DAN PEMBAHASAN}

Hasil analisis EDS komposisi lapisan kerak pada Candi Borobudur, Candi Mendut, dan Candi Kalasan dari tiap-tiap jenis kerak yang dilaksanakan di Laboratorium SEM Fakultas Matematika dan IImu Pengetahuan Alam, Institut Teknologi Bandung dapat dilihat seluruhnya dalam lampiran. Hasil analisis tersebut dirangkum dalam bentuk table dan grafik untuk memudahkan dalam pembacaan. Adapun tabel dan grafik tersebut sebagai berikut: 
Tabel 1. Komposisi Lapisan Kerak Candi Borobudur, Mendut dan Kalasan serta

Batu Segar Candi Kalasan

\begin{tabular}{|c|c|c|c|c|c|c|c|c|c|c|c|c|}
\hline \multirow{2}{*}{$\begin{array}{c}\text { Asal } \\
\text { Sampel (Kode) }\end{array}$} & \multicolumn{12}{|c|}{ Jenis Mineral (\%) } \\
\hline & C & $\mathrm{Na}_{2} \mathrm{O}$ & MgO & $\mathrm{Al}_{2} \mathrm{O}_{3}$ & $\mathrm{SiO}_{2}$ & $\mathrm{P}_{2} \mathrm{O}_{5}$ & $\mathrm{~s}$ & $\mathrm{CaO}$ & $\mathrm{FeO}$ & $\mathrm{K}_{2} \mathrm{O}$ & MnO & $\mathrm{CuO}$ \\
\hline Batu segar K. & 0 & 5.52 & 0 & 21.05 & 65.45 & 0 & 0 & 4.71 & 0 & 3.27 & 0 & 0 \\
\hline Bajralepa K. & 27.83 & 0.47 & 0.73 & 1.74 & 35.86 & 0 & 0.07 & 32.66 & 0.64 & 0 & 0 & 0 \\
\hline Kerak K. hijau & 8.72 & 0.43 & 0.28 & 4.83 & 13.38 & 1.27 & 41.74 & 29.02 & 0.33 & 0 & 0 & 0 \\
\hline Kerak K. merah & 5.1 & 0.47 & 9.65 & 0.5 & 1.57 & 33.16 & 18.39 & 25.24 & 0 & 0 & 5.62 & 0.3 \\
\hline Kerak K. putih & 10.58 & 0.36 & 0 & 31.42 & 7.94 & 34.85 & 8.78 & 4.82 & 0.73 & 0 & 0 & 0.52 \\
\hline Kerak B. & 15.63 & 0 & 0.38 & 9.15 & 71.8 & 0 & 0 & 2.59 & 0.25 & 0 & 0 & 0.21 \\
\hline Kerak M. & 6.18 & 0.97 & 0.28 & 3.45 & 66.91 & 0 & 12.42 & 9.02 & 0.77 & 0 & 0 & 0 \\
\hline
\end{tabular}

Keterangan :

$\begin{array}{lll}\mathrm{B} & : & \text { Candi Borobudur } \\ \mathrm{K} & : & \text { Candi Kalasan } \\ \mathrm{M} & : & \text { Candi Medut } \\ \mathrm{C} & : & \text { karbon } \\ \mathrm{S} & : & \text { sulfur } \\ \text { Batu segar } & : & \text { batu yang dianggap belum mengalami proses pelapukan }\end{array}$

Berdasarkan hasil analisis tersebut secara keseluruhan menunjukkan bahwa semua lapisan kerak pada Candi Borobudur, Candi Mendut, dan Candi Kalasan mengandung unsur karbon, begitu juga pada lapisan bajralepa Candi Kalasan. Mineral fosfat $\left(\mathrm{P}_{2} \mathrm{SO}_{4}\right)$ juga ditemukan pada lapisan kerak Candi Kalasan. Begitu juga unsure belerang (S) ditemukan pada lapisan kerak pada Candi Kalasan dan Candi Mendut. Adanya unsur karbon, fosfat, dan belerang mengindikasikan bahwa dalam lapisan kerak maupun dalam bajralepa terdapat material organik selain material anorganik. Sebagai pembanding hasil analisis batu segar Candi Kalasan tidak mengandung unsur karbon dan sulfur serta fosfat. Hasil ini menunjukkan bahwa batu hanya mengandung material anorganik. Adanya material organik pada seluruh lapisan kerak memungkinkan material tersebut berasal dari aktifitas organisme, karena pada bagian dalam Candi Kalasan dahulu sering dijadikan sebagai sarang kelelawar atau kemungkinan pada lapisan bajralepa terdapat campuran material organik karena kandungan karbon dalam bajralepa cukup tinggi yaitu $27,83 \%$. Akan tetapi dugaan ini perlu untuk dilakukan analisis lanjutan untuk memastikan komposisi jenis material organik dalam lapisan bajralepa.

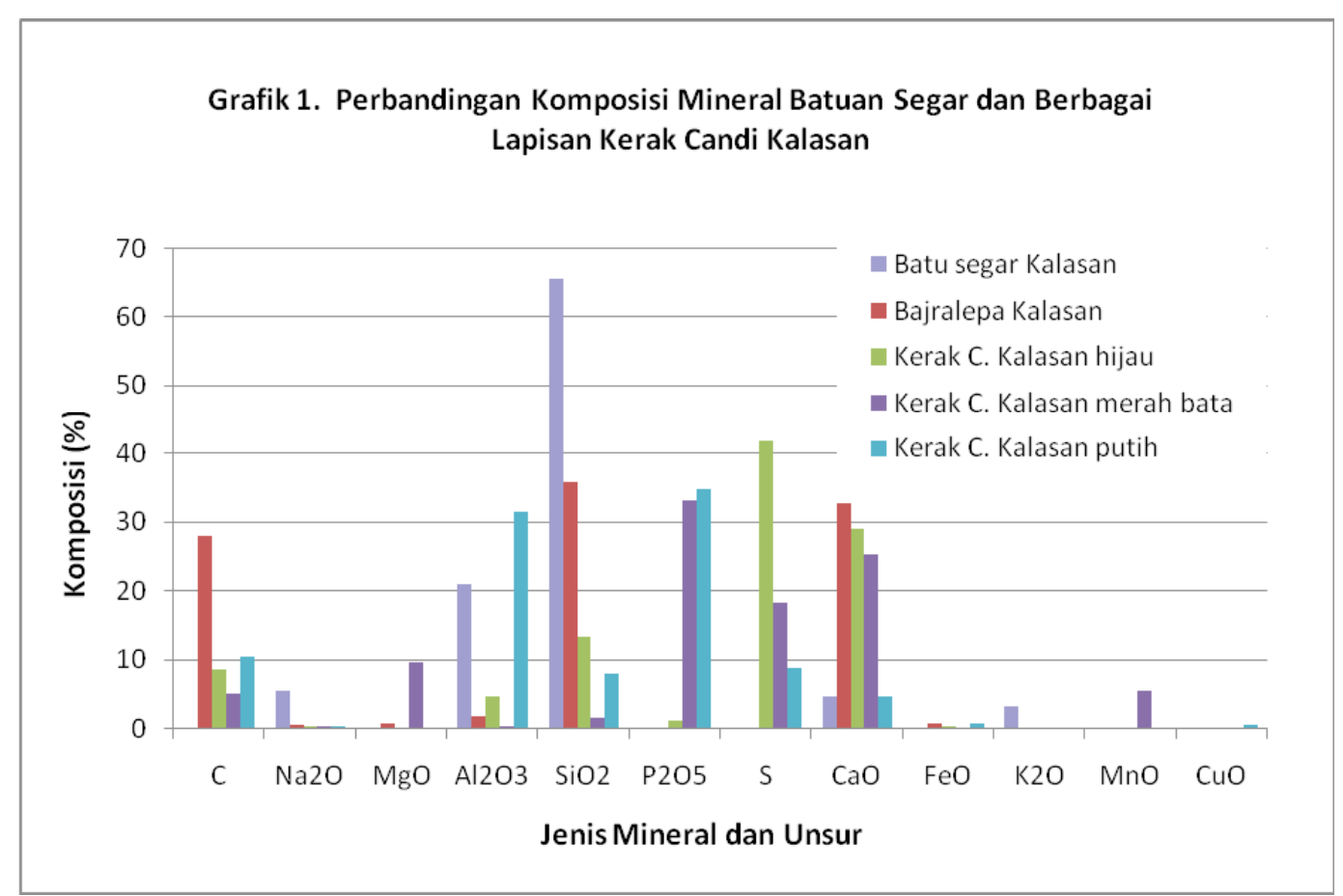


Tabel 2. Tingkat Kekerasan Lapisan Kerak (skala Mosh)

\begin{tabular}{|c|c|c|c|c|c|}
\hline \multirow{2}{*}{ Lokasi } & \multirow{2}{*}{ Warna } & \multicolumn{3}{|c|}{ Ulangan } & \multirow{2}{*}{ Rata-rata } \\
\hline & & & 2 & 3 & \\
\hline Cand Borobudur & putih & 4 & 5 & 6 & 5.0 \\
\hline Candi Mendut & putih & 5 & 3 & 4 & 4.0 \\
\hline Candi Kalasan & hijau & 2 & 2 & 3 & 2.3 \\
\hline Candi Kalasan & merah bata & 2 & 2 & 2 & 2.0 \\
\hline Candi kalasan & putih & 2 & 2 & 2 & 2.0 \\
\hline
\end{tabular}

berturut-turut dari yang tinggi ke rendah lapisan kerak warna putih $(0,73 \%)$, lapisan kerak warna hijau (0,33\%), dan lapisan kerak warna merah bata (0\%). Komposisi kandungan magnesium oksida ( $\mathrm{MgO})$ dan besi oksida ( $\mathrm{FeO}$ ) dalam lapisan kerak Candi Kalasan semakin memperkuat dugaan bahwa lapisan kerak Candi Kalasan berasal dari lapisan bajralepa. Kandungan besi oksida (FeO) Candi Borobudur dan Candi Mendut relative rendah yakni berturut $0,25 \%$ dan $0,77 \%$.

Berdasarkan Tabel 1 dan Grafik 1 dapat diketahui pula bahwa kandungan mineral atau unsur tertinggi pada masing-masing lapisan kerak. Lapisan kerak warna hijau Candi Kalasan didominasi oleh unsur belerang sebesar $(41,74 \%)$, sedangkan lapisan kerak warna merah bata dan warna putih didominasi oleh mineral $\mathrm{P}_{2} \mathrm{O}_{5}$ berturut-turut 33,16\% dan 34,85\%. Sedangkan kandungan mineral tertinggi dalam lapisan kerak Candi Borobudur dan Candi Mendut adalah mineral silica berturut-turut $71,8 \%$ dan $66,91 \%$.

\section{A. Kelarutan Kalsium (Ca) dan Magnesium (Mg) dalam Larutan EDTA}

a) Kelarutan Kalsium dan Magnesium Lapisan Kerak Candi Borobudur dalam Larutan EDTA

Hasil analisis AAS, kelarutan kalsium dan magnesium ditampilkan dalam Grafik 2 untuk memudahkan dalam pembacaan. Grafik 2. menunjukkan bahwa unsur kalsium dan magnesium pada lapisan kerak dapat larut dalam larutan EDTA. Grafik tersebut juga menunjukkan bahwa konsentrasi EDTA dan waktu tidak berpengaruh terhadap kelarutan EDTA. Sehingga pada konsentrasi EDTA $10 \%$ dan waktu kontak 24 jam sudah menunjukkan hasil yang optimum. Hasil ini sama dengan hasil penelitian pada tahap I, konsentrasi EDTA $10 \%$ sudah menunjukkan hasil yang optimum.

b) Kelarutan Kalsium dan Magnesium Lapisan Kerak Candi Medut dalam Larutan EDTA

Hasil analisis AAS kelarutan kalsium dan magnesium pada lapisan kerak Candi Mendut ditampilkan dalam Grafik 3. Berdasarkan grafik tersebut dapat diketahui bahwa perlakukan konsentrasi dan lamanya waktu aplikasi tidak berpengaruh terhadap hasil kelarutan kalsium dan magnesium pada lapisan kerak Candi Kalasan. Grafik tersebut menunjukkan bahwa larutan EDTA dengan konsentrasi antara 3-5\% sudah menunjukkan hasil yang optimum dalam 

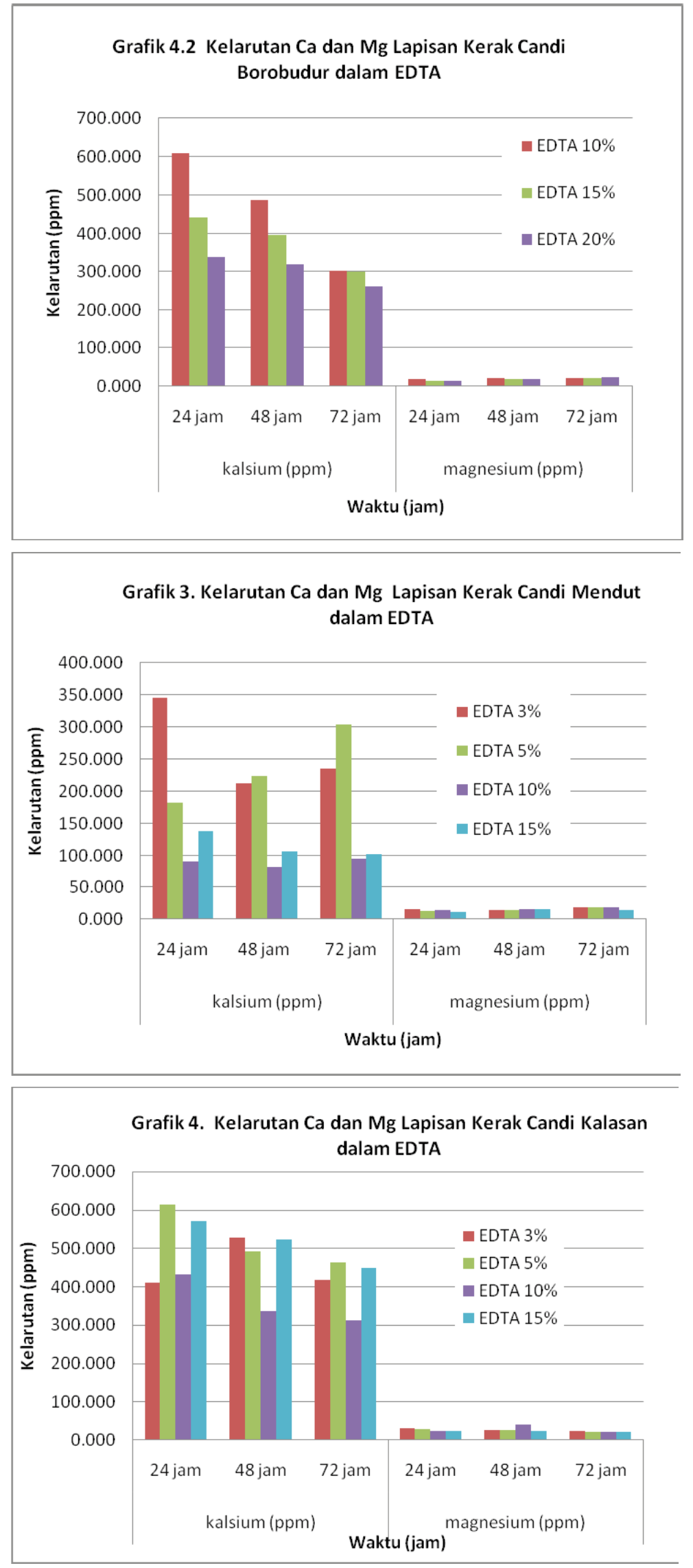

melarutkan kalsium dan magnesium dalam lapisan kerak pada Candi Mendut. Sekalipum magnesium yang larut sangat kecil karena persentase magnesium dalam lapisan kerak sangat rendah.

c) Kelarutan Kalsium dan Magnesium Lapisan Kerak Candi Kalasan dalam Larutan EDTA Hasil analisis AAS kelarutan kalsium dan magnesium dalam lapisan kerak Candi Kalasan ditampilkan dalam Grafik 4. Berdasarkan grafik tersebut diketahui bahwa kalsium dan magnesium dapat larut dalam larutan EDTA. Akan tetapi perlakukan konsentrasi dan lamanya waktu aplikasi tidak berpengaruh terhadap tingkat kerarutan kalsium dan magnesium pada lapisan kerak Candi Kalasan. Grafik tersebut menunjukkan bahwa pada konsentarasi $5 \%$ dan lama waktu aplikasi 24 jam sudah menunjukkan hasil optium untuk melarutkan lapisan kerak pada Candi Kalasan.

\section{B. Kelarutan Besi ( $\mathrm{Fe}$ ) dan Tembaga ( $\mathrm{Cu}$ ) dalam Larutan EDTA}

a) Kelarutan Besi (Fe) dan Tembaga (Cu) pada Lapisan Kerak Candi Borobudur dalam Larutan EDTA

Hasil analisis AAS kelarutan Fe dan $\mathrm{Cu}$ pada lapisan kerak Candi Borobudur dalam larutan EDTA disajikan dalam bentuk Grafik 5. Grafik tersebut menunjukkan bahwa besi dan tembaga dalam lapisan kerak dapat larut oleh larutan EDTA. Akan tetapi perlakuan konsertrasi dan lamanya waktu aplikasi relative tidak berpengaruh terhadap kelarutan besi dan tembaga. Hasil analisis menunjukkan bahwa pada konsentrasi $10 \%$ dan waktu 24 jam sudah menunjukkan hasil yang optimum dalam melarutkan besi dan tembaga dalam lapisan kerak.

b) Kelarutan Besi (Fe) dan Tembaga (Cu) pada Lapisan Kerak Candi Mendut dalam Larutan EDTA

Hasil analisis AAS, kelarutan Fe dan Cu pada lapisan kerak Candi Mendut dalam larutan EDTA ditampilkan dalam bentuk Grafik 6. Berdasarkan grafik tersebut diketahui besi larut dalam lapisan kerak dapat larut dalam EDTA tetapi relative tidak ada tembaga yang larut dalam EDTA. Hal ini karena memang unsur tembaga dalam lapisan kerak tidak terdeteksi. Grafik tersebut juga menunjukkan 
bahwa perlakuan konsentrasi dan lamanya waktu aplikasi relative tidak berpengaruh terhadap kelarutan besi dalam EDTA. Pada konsentrasi 3\% dan waktu aplikasi 24 jam sudah menunjukkan hasil yang optimum.

c) Kelarutan Besi (Fe) dan Tembaga (Cu) pada Lapisan Kerak Candi Kalasan dalam Larutan EDTA

Hasil analisis AAS kelarutan besi dan tembaga pada lapisan kerak Candi Kalasan dalam larutan EDTA disajikan dalam bentuk Grafik 7. Berdasarkan grafik tersebut diketahui bahwa besi dan tembaga dapat larut dalam larutan EDTA. Akan tetapi perlakuan konsentrasi dan lamanya waktu aplikasi EDTA tidak berpengaruh terhadap kelarutan besi dan tembaga. Diketahui pula kelarutan besi pada lapisan kerak optimum pada konsentrasi larutan EDTA 3\% dan waktu aplikasi 24 jam.

\section{Tingkat Kebersihan Permukaan Batu Uji}

a) Candi Kalasan

Tingkat kebersihan permukaan batu uji di Candi Kalasan dapat diketahui melalui hasil digitalisasi luasan permukaan lapisan kerak sebelum dan sesudah perlakukan. Adapun data hasil digitalisasi kami paparkan dalam tabel 3.

Berdasarkan data dalam Table 3. tersebut menunjukkan bahwa konsentrasi EDTA 5\% menunjukkan tingkat kebersihan paling tinggi dibandingkan dengan perlakuan lainnya. Tingkat kebersihan batu uji pada perlakuan EDTA 5\% adalah 58\%, ini artinya perbedaan luasan permukaan kerak sebelum dan sesudah perlakukan sebesar 58\%. Jika melihat data tersebut di atas terdapat ketidakseragaman data, hal ini kemungkinan karena komposisi kimia kerak pada permukaan batu tidak seragam atau tidak sama persis (lihat kembali data komposisi kerak pada Candi Kalasan dalam Tabel 1). Untuk mengetahui apakah metode pembersihan garam sudah efektif atau belum maka diketahui dengan menghitung jumlah tenaga dan bahan yang digunakan serta resiko dari penggunaan bahan tersebut. Waktu dan bahan yang digunakan untuk membersihkan luas permukaan kerak $20 \mathrm{~cm} \times 10 \mathrm{~cm}$ dengan konsentrasi EDTA 5\% maka berdasarkan analisis harga satuan setiap pembersihan
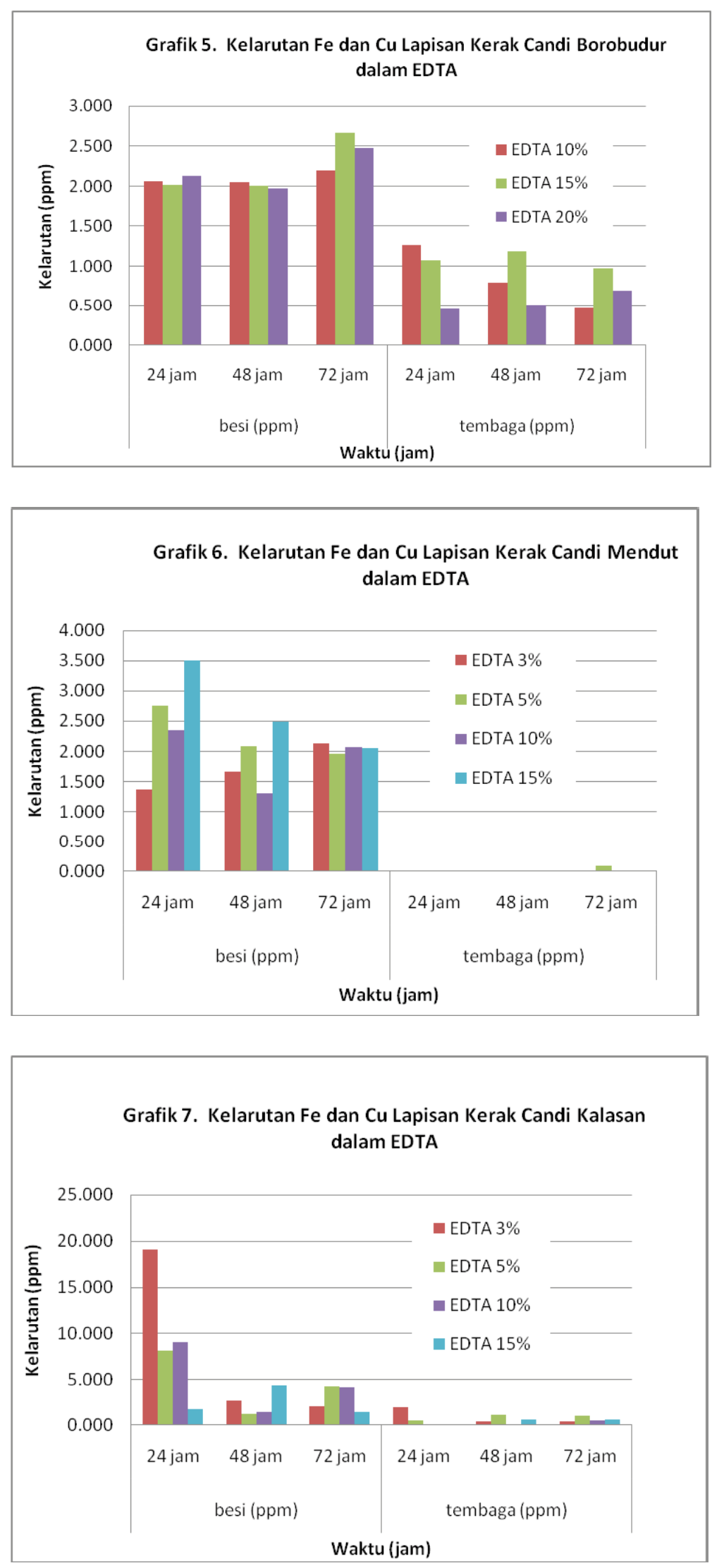
0,02 $\mathrm{m}^{2}$ membutuhkan biaya $\mathrm{Rp} 257.200,00$ sehingga untuk pembersihan EDTA seluas $1 \mathrm{~m}^{2}$ membutuhkan biaya sebesar Rp 13.760.000,00 dengan tingkat kebersihan hanya 58\% (lihat lampiran analisis harga satuan). Berdasarkan pehitungan tersebut maka metode pembersihan endapan garam Candi Kalasan menggunakan EDTA tidak efektif untuk diterapkan.

\section{b) Candi Borobudur}

Perbandingan luas lapisan kerak sebelum dan sesudah perlakuan menunjukkan tidak ada perbedaan terhadap tingkat kebersihan (lihat Tabel 4). Bila dikaitkan dengan komposisi lapisan kerak pada Candi Borobudur yang menunjukkan kandungan mineral silikanya sangat tinggi $(71,8 \%)$ maka hasil tersebut menunjukkan bahwa EDTA sukar untuk melarutkan endapan silica. EDTA hanya cepat melarutkan lapisan kerak dalam bentuk logam seperti Mg, Cu dan Fe. Tetapi karena jumlah $\mathrm{Mg}, \mathrm{Ca}$, dan Fe rendah maka perlakuan dengan menggunakan EDTA tidak menunjukkan adanya perbedaan luasan lapisan kerak sebelum dan sesudah perlakuan.

\section{c) Candi Mendut}

Tingkat kebersihan setelah perlakuan dengan larutan EDTA pada batu uji di Candi Mendut dapat dilihat pada Tabel 5 . Hasil digitalisasi tersebut menunjukkan bahwa permbersihan terhadap kerak pada permukaan batu uji tidak berpengaruh. Hal ini karena kandungan utama kerak pada Candi Mendut adalah mineral silica (lihat Tabel 1). Mineral silica merupakan mineral yang sukar larut dalam larutan asam, meskipun dalam reaksi jangka panjang mineral tersebut dapat larut. Sedangkan kandungan kalsium dan magnesium dalam kerak dapat larut oleh EDTA tetapi komposisi kedua unsur tersebut sangat rendah. Sehingga kelarutan kedua unsur tersebut dalam EDTA tidak berpengaruh terhadap tingkat kebersihan batu uji.

Tabel 3. Prosentase Tingkat Kebersihan Candi Kalasan

\begin{tabular}{|rrrrr|} 
No & Lokasi & Sebelum treatmen & Area yang bersih & Persentase Tingkat Kebersihan \\
\hline 1 & $3 \%$ & 590,7219 & 117,3110 & $20 \%$ \\
\hline 2 & $5 \%$ & 567,0306 & 330,3068 & $58 \%$ \\
\hline 3 & $10 \%$ & 558,6678 & 95,5535 & $17 \%$ \\
\hline 4 & $15 \%$ & 569,1990 & 286,1230 & $50 \%$ \\
\hline
\end{tabular}

Tabel 4. Prosentase Tingkat Kebersihan Candi Borobudur

\begin{tabular}{|ccccc|}
\hline No & Lokasi & Sebelum Treatmen & Area yang Bersih & Persentase Tingkat Kebersihan \\
\hline 1 & $10 \%$ & 779,43 & 779,43 & $0 \%$ \\
\hline 2 & $15 \%$ & 774,91 & 774,91 & $0 \%$ \\
\hline 3 & $20 \%$ & 784.03 & 784.03 & $0 \%$ \\
\hline
\end{tabular}

Tabel 5 Prosentase Tingkat Kebersihan Candi Mendut

\begin{tabular}{|ccccc|}
\hline No & Lokasi & Sebelum Treatmen & Area yang Bersih & Persentase Tingkat Kebersihan \\
\hline 1 & $3 \%$ & 154,767 & 154,767 & $0 \%$ \\
\hline 2 & $5 \%$ & 351,204 & 351,204 & $0 \%$ \\
\hline 3 & $10 \%$ & 166,369 & 166,369 & $0 \%$ \\
\hline 4 & $15 \%$ & 168,823 & 168,763 & $0 \%$ \\
\hline
\end{tabular}




\section{Fluktuasi Suhu dan Kelembaban Selama Penelitian}

Dalam kajian ini dilakukan pemantauan suhu dan kelembapan pada Candi Kalasan, Borobudur dan Mendut. Data suhu dan kelembapan tersebut selama penelitian penting untuk mengetahui tingkat fluktuasi suhu dan kelembapan yang berpengaruh terhadap proses pembentukan lapisan kerak.

\section{a) Candi Kalasan}

Berdasarkan hasil perekaman data longger pada suhu dan kelembapan udara Candi Kalasan selama penelitian menunjukkan bahwa terjadi fluktuasi suhu dan kelembapan yang tinggi pada bagian luar bangunan candi dengan selisih sebesar $7,96^{\circ} \mathrm{C}$ dari suhu terendah $\left(24,4^{\circ} \mathrm{C}\right)$ dan suhu tertinggi $\left(32,36^{\circ} \mathrm{C}\right)$. Sedangkan pada bagian dalam Candi Kalasan fluktuasi suhu dan kelembaban udara terjadi relative lebih rendah yakni sebesar $4,66^{\circ} \mathrm{C}$ dari suhu terendah $\left(24,73^{\circ} \mathrm{C}\right)$ dan suhu tertinggi $\left(29,39^{\circ} \mathrm{C}\right)$. Fluktuasi kelembaban udara pada bagian luar sebesar $31,06 \%$ dengan kelembaban terendah sebesar $53,38 \%$ sedangkan kelembaban tertinggi $84,44 \%$. Sedangkan fluktuasi kelembaban yang terjadi pada bagian dalam bangunan candi sebesar $8,67 \%$ dengan kelembapan terendah $81,76 \%$ dan kelembaban tertinggi $90,36 \%$.

Berdasarkan data dan Grafik 8. tersebut diketahui adanya fluktuasi suhu dan kelembaban yang tinggi dan temperature yang tinggi pada bagian luar bangunan candi, sedangkan pada bagian dalam kelembapan udara sangat tinggi dan fluktuasi suhu serta kelembaban udara relative lebih rendah. Kondisi ini yang menyebabkan dinding bagian dalam bangunan Candi Kalasan banyak terdapat lapisan kerak tetapi proses pengeringan endapan terjadi dalam waktu yang relative lambat, sehingga proses kristalisasi kerak terjadi dalam proses yang lambat pula. Proses kristalisasi garam yang lambat tersebut menyebabkan lapisan kerak Candi Kalasan relatif lunak selain karena faktor komposisi dari lapisan kerak itu sendiri (lihat Tabel 1).

\section{b) Candi Borobudur}

Hasil perekaman data lodger suhu dan kelembaban udara menunjukkan adanya fluktuasi suhu dan kelembaban udara yang tinggi pada Candi Borobudur. Selisih suhu terendah $\left(23,09^{\circ} \mathrm{C}\right)$ dan tertinggi $\left(32,77^{\circ} \mathrm{C}\right)$ pada bagian selasar sisi selatan sebesar $9,68^{\circ} \mathrm{C}$ sedangkan pada bagian lorong sisi barat sebesar $11,77^{\circ} \mathrm{C}$ dari suhu terendah $23,09^{\circ} \mathrm{C}$ dan tertinggi $34,86^{\circ} \mathrm{C}$. Sementara itu fluktuasi kelembapan udara pada bagian selasar sisi selatan sebesar 38,33\% dari kelembaban udara terendah $54,63 \%$ dan kelembaban udara tertinggi $92,96 \%$, sedangkan fluktuasi kelembaban udara pada lorong sisi barat sebesar $39,42 \%$ dengan kelembaban udara terendah $48,7 \%$ dan kelembaban udara tertinggi sebesar $88,12 \%$.

Fluktuasi suhu dan kelembaban udara pada bagian lorong Candi Borobudur lebih besar dibandingkan pada bagian selasar, kondisi ini yang kemungkinan menyebabkan kerusakan dan pelapukan pada batu-batu dinding lorong lebih besar dibandingkan pada bagian dinding selasar. Selain karena faktor-faktor lain yang ikut berperan dalam mempercepat kerusakan dan pelapukan batu-batu pada dinding lorong.

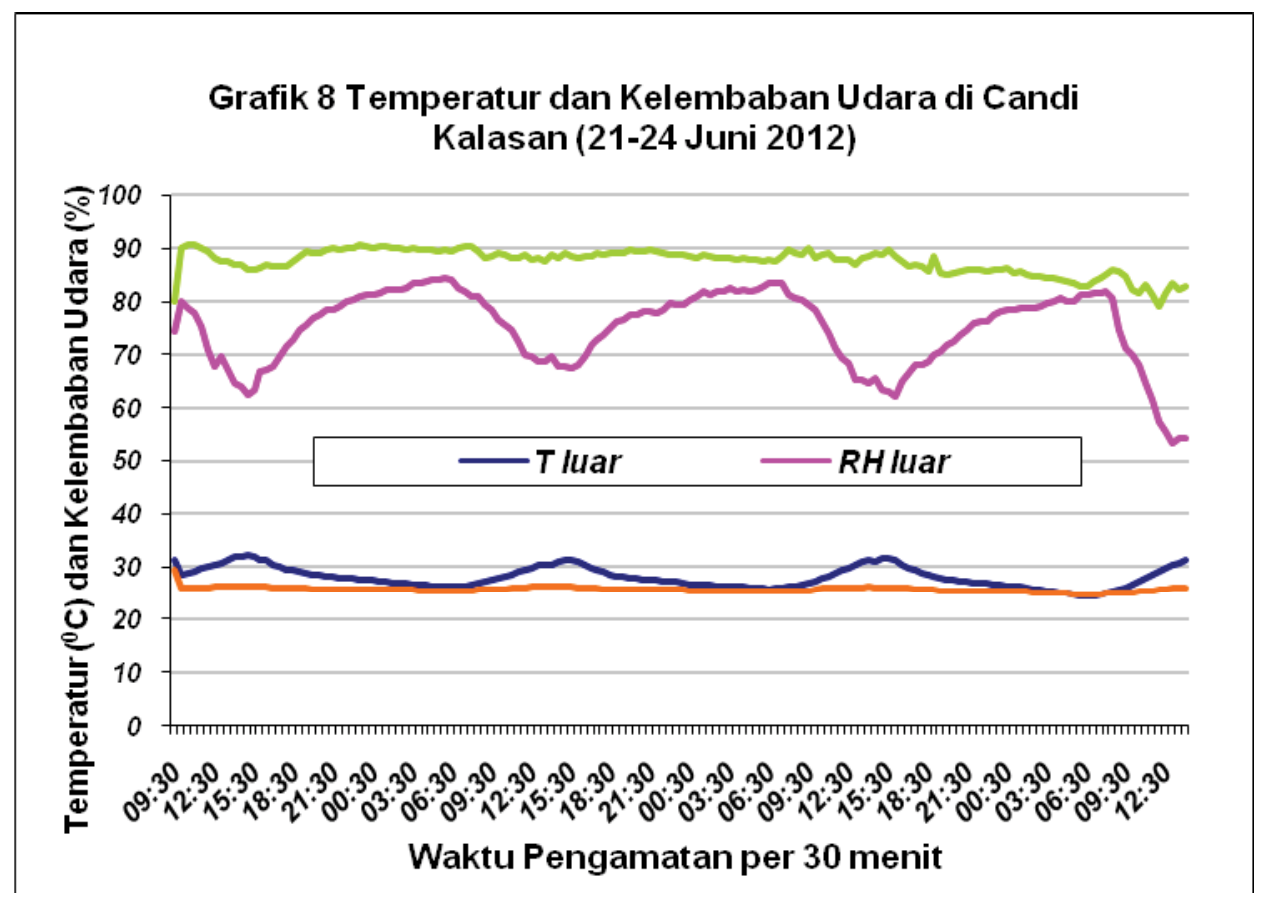



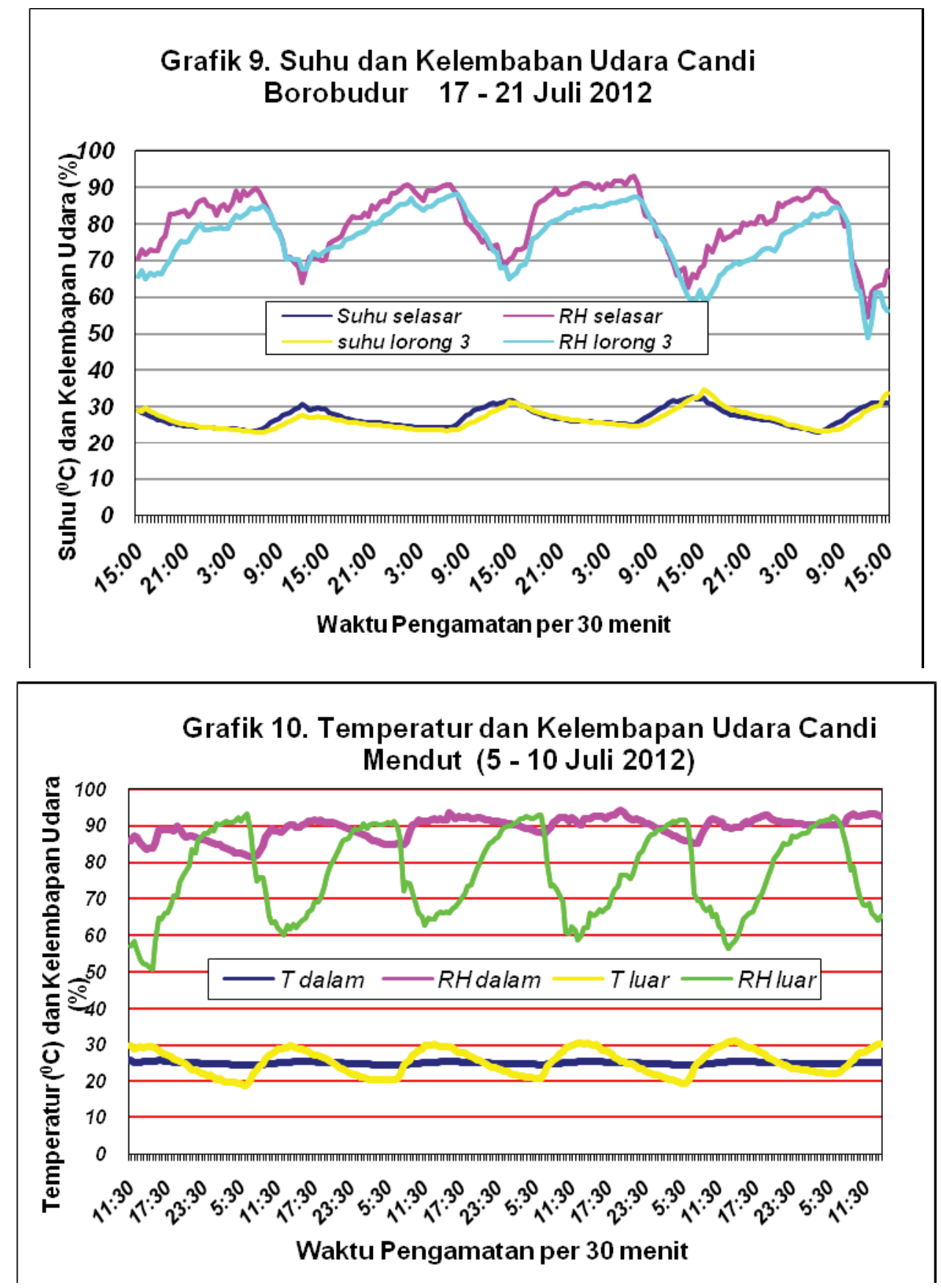

\section{c) Candi Mendut}

Berdasarkan hasil perekaman data lodger menunjukkan adanya fluktuasi suhu dan kelembaban udara yang tinggi pada bagian luar Candi Mendut, sedangkan pada bagian dalam candi relative stabil. Fluktuasi suhu udara pada bagian luar sebesar $12,13^{\circ} \mathrm{C}$ dengan suhu udara tertinggi $31,13^{\circ} \mathrm{C}$ dan suhu terendah $18,87^{\circ} \mathrm{C}$. Sedangkan fluktuasi kelembaban udara pada bagian luar Candi Mendut sebesar 42,49\% dengan kelembaban udara tertinggi 93,14\%. Sedangkan fluktuasi suhu udara pada bagian dalam Candi Medut hanya sebesar $1,07^{\circ} \mathrm{C}$ dengan suhu terendah $24,58^{\circ} \mathrm{C}$ dan suhu tertinggi $25,6^{\circ} \mathrm{C}$ dan besarnya fluktuasi kelembaban pada bagian dalam
Candi Mendut sebesar 12,08\% dengan kembaban udara terendah 81 , 39\% dan kelembaban udara tertinggi $93,47 \%$.

Fluktuasi suhu dan kelembaban udara yang tinggi pada bagian luar Candi Mendut kemungkinan yang berpengaruh terhadap proses kristalisasi lapisan kerak pada dinding bagian luar. Sehingga lapisan kerak pada bagian luar bangunan Candi Mendut lebih keras dari pada lapisan kerak pada bagian dalam. Di mana kekerasan lapisan kerak pada bagian luar antara 4-5 skala mosh sedangkan kerak pada bagian dalam antara 3-5 skala mosh. 


\section{KESIMPULAN DAN SARAN}

\section{A. Kesimpulan}

1. Komposisi lapisan kerak pada Candi Borobudur, Candi Mendut, dan Candi Kalasan terdiri dari material organik dan an-organik. Didapatkannya unsur karbon (C), sulfur (S), dan phospat (P) mengidikasikan adanya material organik sedangkan didapatkanya unsur silica ( $\mathrm{Si}$ ), almunium (Al), magnesium (mg), besi (Fe) dan lain-lain mengindikasikan adanya material anorganik.

2. Peningkatan konsentrasi EDTA dan lamanya waktu aplikasi tidak berpengaruh terhadap kelarutan logam kalsium (Ca), magnesium $(\mathrm{Mg})$, besi $(\mathrm{Fe})$, dan tembaga ( $\mathrm{Cu}$ ).

- Konsentrasi EDTA $10 \%$ dan waktu kontak 24 jam sudah menunjukkan hasil yang optimum dalam melarutkan $\mathrm{Ca}, \mathrm{Mg}, \mathrm{Fe}$, dan $\mathrm{Cu}$ pada lapisan kerak Candi Borobudur.

- Konsentrasi EDTA 3\% dengan waktu kontak 24 jam sudah optimum untuk melarutkan $\mathrm{Ca}$ dan $\mathrm{Mg}$ dan konsentarsai $15 \%$ untuk melarutkan Fe pada lapisan kerak Candi Mendut.

- Konsentrasi EDTA 5\% dengan waktu kontak 24 jam menunjukkan hasil optimum melarutkan Ca dan Mg dalam lapisan kerak Candi Kalasan,

\section{DAFTAR PUSTAKA}

Ariyanto, T.B.1993.DampakPerawatanCandiBorobudur terhadap Bangunan dan Lingkungan. Balai Studi dan Konservasi Borobudur, Magelang.

Croci, Giorgio. 1989. The Conservation and Structural Restoration of Architectural Heritage. Computational Mechanics Publication Southmpton, UK and Boston, USA.

Graha, D.S. 1987. Batuan dan Mineral. Nova, Bandung.

Lange, M., Ivanova, M., and Lebedeva, N. (Silitonga, E.J). 1991. Geologi Umum. Gaya Media Pratama, Jakarta.

Pescok, R.L., Shields, L.D., Caims, T., and Mc William, I.G. 1968. Modern Methods of Chemical Analysis. Secound edition, John and Sons, New York.

\section{Publikasi Hasil Penelitian, Skripsi, Tesis dan Artikel}

Safaat, Sandi. 2004. Kajian Pengaruh Temperatur dan Konsentrasi Larutan EDTA pada Proses Aktifasi Zeolit Alam dengan Metode Disolusi sedangkan untuk melarutkan Fe dan Cu optimum pada konsentrasi EDTA 3\% dengan waktu kontak 24 jam.

3. Hasil digitalisasi menunjukkan adanya perbedaan luasan lapisan kerak Candi Kalasan sebesar 58\% setelah perlakukan dengan EDTA $5 \%$, sedangkan pada Candi Borobudur dan Mendut tidak menunjukkan adanya perbedaan luasan permukaan lapisan kerak baik sebelum maupun sesudah perlakukan. Sehingga metode pembersihan lapisan kerak menggunakan EDTA tidak dapat membersihkan lapisan kerak secara menyeluruh.

4. Dilihat dari segi teknis pengerjaan dan hasil yang diperoleh, ternyata pembersihan lapisan kerak pada permukaan batu candi menggunakan larutan EDTA ini belum efektif. Hal ini didasarkan pada perhitungan waktu, biaya dan resiko.

\section{B. Saran}

Perlu dilaksanakan penelitian lanjutan untuk mencari metode alternatif dalam pembersihan lapisan kerak pada permukaan batu candi yang lebih efektif, efisien, tidak merusak material cagar budaya serta ramah terhadap lingkungan.

dalam Larutan Na2EDTA. (Skripsi). Fakultas Matematika dan IImu Pengetahuan Alam, Universitas Gadjah Mada, Yogyakarta

Salimin, Zainus; Gunandjar. 2006. Penggunaan EDTA sebagai Pencegah Kerak pada Evaporasi Limbah Radioaktif Cair. Pusat Teknologi Limbah Radioaktif, Batan

Suharyadi. 1984. Geologi Teknik untuk Teknik Sipil. Fakultas Teknik, Universitas Gadjah Mada, Yogyakarta.

Torraca, Giorgio. 1982. Porous Building MaterialMaterialScienceforArchitecturalConservation. ICCROM, Roma Italy.

Vercoef. 1992. Geologi untuk Teknik Sipil. Jakarta.

Winarno, S. 2001. Peranan Laboratorium dalam Konservasi Benda Cagar Budaya. Makalah disampaikan dalam Penataran Tenaga Teknis Kepurbakalaan Tingkat Dasar di Bogor, 4-18 September 2001. 